\title{
KAJIAN EVALUASI TENAGA PENDIDIKAN DALAM RANGKA PENINGKATAN KUALITAS PENDIDIKAN DI KUTAI KARTANEGARA PROVINSI KALTIM
}

\author{
EVALUATION STUDY OF LABOR EDUCATION \\ IN ORDER TO IMPROVING THE QUALITY OF EDUCATION \\ IN THE KUTAI KARTANEGARA EAST KALIMANTANPROVINCE
}

\author{
Muhammad Soleh Pulungan \\ Balitbangda Kab. Kutai Kartanegara Provinsi Kaltim \\ Jl. WR. Mongonsidi Komplek Kantor Bupati Gedung Bappeda Lt. 4 Tenggarong 75511 \\ HP. 0852.5025.3454 \\ Email: solehpulungan66@gmail.com \\ Dikirim : 9 Januari 2015 Direvisi: 14 Maret 2015 Disetujui: 12 Mei 2015
}

\begin{abstract}
Abstrak
Peningkatan kualitas sumber daya manusia mutlak diperlukan dalam proses pembangunan sektor pendidikan di era globalisasi. Tujuan pengkajian ini adalah; Untuk mengevaluasi penempatan tenaga pendidikan sesuai dengan kompetensi, Untuk menganalisis standar kualifikasi tenaga pendidikan, Untuk mengetahui standar kualitas pendidikan di Kab. Kutai Kartanegara. Metode Penelitian yang dilakukan secara survey, dengan populasi adalah kepala sekolah dan guru SD, SMP dan SMA, dengan tiga zona, yakni: zona I, II, dan III di Kutai Kartanegara. Hasil Penelitian; Standar Pendidikan yang dimiliki para guru cukup tinggi, dengan spesialisasi tertentu. Kekurangan tenaga pendidik bidang studi tertentu, mengakibatkan sebagian guru mengajar tidak sesuai keahliannnya. Untuk lebih meningkatkan kualitas guru disarankan untuk aktif mengikuti seminar, workshop, dan pelatihan. Strategi pembangunan pendidikan tidak hanya berdasarkan pada input oriented saja, tetapi juga harus lebih memperhatikan faktor proses pendidikan. Peranan pemerintah melalui Dinas Pendidikan diharapkan untuk melakukan analisis kebutuhan guru setiap tahun, perbaikan dan peningkatan sarana prasarana sekolah, sesuai kebutuhan masing-masing.

Kata Kunci: Pendidikan, guru, evaluasi, peningkatan, kualitas, sarana
\end{abstract}

\begin{abstract}
Improving the quality of human resources is absolutely necessary in the process of education sector development in the era of globalization. The purpose of this study is; To evaluate the placement of education according to the competence, To analyze the qualification standards of education, To determine the quality standards of education in the district Kutai Kartanegara. Methods Research conducted a survey, the population is the principal and elementary teacher, junior high and high school, with three zones, namely: zone I, II, and III in Kutai. Research Result; Education standards that teachers have high enough, with a particular specialization. Disadvantages educators particular field of study, resulting in the majority of teachers do not teach according keahliannnya. To further improve the quality of teachers are advised to actively participate in seminars, workshops, and training. Education development strategy is not only based on the input oriented, but also must pay more attention to the educational process factors. The role of the government through the Department of Education is expected to conduct a needs analysis of teachers every year, repair and improvement of school infrastructure, according to the needs of each.
\end{abstract}

Keywords: Education, teachers, evaluation, improvement, quality, means

\section{PENDAHULUAN}

Perkembangan ilmu pengetahuan dan teknologi telah membawa perubahan di hampir semua aspek kehidupan manusia dimana berbagai permasalahan hanya dapat dipecahkan kecuali dengan upaya penguasaan dan peningkatan ilmu pengetahuan dan teknologi. Selain manfaat bagi kehidupan manusia di satu sisi perubahan tersebut juga telah membawa manusia ke dalam era persaingan global yang semakin ketat. Agar mampu berperan dalam persaingan global, maka sebagai bangsa kita perlu terus mengembangkan dan meningkatkan kualitas sumber daya manusianya. Oleh karena itu, peningkatan kualitas sumber daya manusia merupakan kenyataan yang harus dilakukan secara terencana, terarah, insentif, efektif dan efisien dalam proses pembangunan, kalau tidak ingin bangsa ini kalah bersaing dalam menjalani era globalisasi tersebut.

Fakta membuktikan secara internasional bahwa kualitas pendidikan Indonesia masih tertinggal berada di peringkat ke-64 dari 120 negara di seluruh dunia berdasarkan laporan tahunan 
UNESCO Education For All Global Monitoring Report 2012. Sedangkan berdasarkan Indeks Perkembangan Pendidikan (Education Development Index, EDI), Indonesia berada pada peringkat ke-69 dari 127 negara pada 2011. Dalam laporan terbaru Program Pembangunan PBB tahun 2013, Indonesia menempati posisi 121 dari 185 negara dalam Indeks Pembangunan Manusia (IPM) dengan angka 0,629. Dengan angka itu Indonesia tertinggal dari dua negara tetangga ASEAN yaitu Malaysia (peringkat 64) dan Singapura (18), sedangkan IPM di kawasan Asia Pasifik adalah 0,683.

Berbicara mengenai kualitas sumber daya manusia, pendidikan memegang peran yang sangat penting dalam proses peningkatan kualitas sumber daya manusia. Peningkatan kualitas pendidikan merupakan suatu proses yang terintegrasi dengan proses peningkatan kualitas sumber daya manusia itu sendiri. Menyadari pentingnya proses peningkatan kualitas sumber daya manusia, maka pemerintah bersama kalangan swasta sama-sama telah dan terus berupaya mewujudkan amanat tersebut melalui berbagai usaha pembangunan pendidikan yang lebih berkualitas antara lain melalui pengembangan dan perbaikan kurikulum dan sistem evaluasi, perbaikan sarana pendidikan, pengembangan dan pengadaan materi ajar, serta pelatihan bagi guru dan tenaga kependidikan lainnya. Tetapi pada kenyataannya upaya pemerintah tersebut belum cukup berarti dalam meningkatkan kualitas pendidikan.

Ada dua faktor yang dapat menjelaskan mengapa upaya perbaikan mutu pendidikan selama ini kurang atau tidak berhasil. Pertama strategi pembangunan pendidikan selama ini lebih bersifat input oriented. Strategi yang demikian lebih oersandar kepada asumsi bahwa bilamana semua input pendidikan telah dipenuhi, seperti penyediaan buku-buku (materi ajar) dan alat belajar lainnya, penyediaan sarana pendidikan, pelatihan guru dan tenaga kependidikan lainnya, maka secara tomatis lembaga pendidikan (sekolah) akan dapat menghasilkan output (keluaran) yang bermutu sebagai mana yang diharapkan.

Kedua, pengelolaan pendidikan selama ini lebih bersifat macro-oriented, diatur oleh jajaran birokrasi. Akibatnya, banyak faktor yang diproyeksikan di tingkat birokrasi tidak terjadi atau tidak berjalan sebagaimana mestinya di tingkat sekolah. Atau dengan singkat dapat dikatakan bahwa kompleksitasnya cakupan permasalahan pendidikan, seringkali tidak dapat terpikirkan secara utuh dan akurat oleh manajemen birokrasi.

Realita tersebut memberikan pemahaman kepada kita bahwa pembangunan pendidikan bukan hanya terfokus pada penyediaan faktor input pendidikan tetapi juga harus lebih memperhatikan faktor proses pendidikan. Input pendidikan merupakan hal yang mutlak harus ada dalam batasbatas tertentu tetapi tidak menjadi jaminan dapat secara otomatis meningkatkan mutu pendidikan (school resources are necessary but not sufficient condition to improve student achievement). Disamping itu mengingat sekolah sebagai unit pelaksana pendidikan formal terdepan dengan berbagai keragaman potensi anak didik yang memerlukan layanan pendidikan yang beragam. Kondisi lingkungan yang berbeda dengan lainnya, maka sekolah harus dinamis dan kreatif dalam melaksanakan perannya untuk mengupayakan peningkatan kualitas/mutu pendidikan.

Menurut informasi Kementerian Pendidikan dan Kebudayaan memprediksi bahwa dalam kurun waktu 2010-2014, ada sekitar 171.109 guru PNS di SD dan SMP pensiun. Jika ditarik lagi hingga 2020, tercatat ada 400 ribu lebih guru yang pensiun. Dunia pendidikan dikhawatirkan terjadinya ancaman paceklik guru PNS. Prediksi tingginya angka pensiun tersebut disebabkan karena pada 1974 silam muncul pengangkatan besar-besaran guru PNS. Jumlahnya mencapai ratusan ribu orang. Kejadian itu muncul karena tahun itu keluar Instruksi Presiden (Inpres) Nomor 1 yang memudahkan pengangkatan guru terutama guru SD.

Sementara itu, Ketua Persatuan Guru Seluruh Indonesia (PGRI) Prof. Sulistyo mengatakan, Indonesia masih kekurangan sekitar 400 ribu guru untuk tingkat Sekolah Dasar (SD). Dia berharap pemerintah membuka lagi daftar calon PNS untuk guru atau mengangkat guru honorer menjadi PNS. Berdasarkan data PGRI, jumlah guru seluruh Indonesia mencapai 2.925.676. Jumlah itu pun belum dipastikan lantaran data soal mutasi guru tidak terekam dengan baik, yang terjadi, guru menumpuk pada jenjang pendidikan SMP dan SMA. Prof. Sulistyo juga menyayangkan data Bank Dunia menyebutkan bahwa jumlah guru SD di Indonesia cukup. Angka Rasio Bank Dunia yakni 1 guru banding 18 murid, persoalannya kapasitas kelas di sebagian besar Indonesia adalah kelas kecil.

Berbagai problem pendidikan yang ada di Indonesia mengindikasikan bahwa apa yang selama ini dilakukan pemerintah dalam penanganan pendidikan tidak sesuai dengan tuntutan kebutuhan pendidikan. Masalah lainnya yang terjadi dala dunia pendidikan adalah ketidakmapanan regulasi yang dapat mengatur masalah pendidikan. Karena kelemahan ini maka sulit bagi pihak-pihak sekolah dan lembaga pendidikan lainnya untuk menetapkan standard pendidikan yang ideal karena sering berhadapan dengan ketidakpastian dan khawatir perbenturan dengan regulasi yang telah dibuat dan ditetapkan pemerintah. Selain hal diatas, pendidikan juga mengahadapi masalah dibidang kesejahteraan tenaga pendidik. Penghasilan yang didapatkan oleh para guru dari pekerjaan/profesi sebagai pengajar/guru relatif tidak mencukupi dengan kebutuhan hidup mereka. Kondisi ini tentu membuat para pendidik tidak dapat berkonsentrasi kepada pekerjaan/profesi mereka sebagai tenaga pendidik. 
Mereka harus mencari sumber-sumber penghasilan diluar agar kebutuhan hidup sehari-hari dapat teratasi sehingga berpengaruh signifikan terhadap konsentrasi mengajar yang ditekuni. Dalam keadaan seperti ini maka sudah dapat dipastikan mengganggu jalannya proses pendidikan. Dan tidak kalah pentingnya untuk dicermati dan dievaluasi adalah masalah kualitas tenaga pendidik, kesesuaian disiplin ilmu dengan bidang yang diajarkan, konsentrasi pendistribusian tenaga pendidik antara daerah perkotaan dengan daerah pedesaan, antara tenaga pendidik Pulau Jawa dan luar Pulau Jawa, standar referensi mengajar, implementasi kurikulum dan lain sebagainya.

Jelas semua ini merupakan faktor-faktor krusial yang akan menentukan apakah pendidikan berkualitas atau tidak. Jika masalah ini terabaikan maka sudah mesti bahwa kualitas pendidikan akan rendah dan outputnya-pun tidak mungkin diharapkan akan mampu memenuhi standar kebutuhan dunia kerja dan kebutuhan pembangunan. Oleh karena itu kajian dan evaluasi terhadap masalah pendidikan sangat diperlukan untuk dapat menentukan langkah dan kebijakan semua pihak dalam membangun dunia pendidikan.

Permasalahan; Kualitas pendidikan sangat dipengaruhi oleh salah beberapa faktor yakni; penempatan yang sesuai terhadap guru, kompetensi guru, dan sejauh ini belum dapat ditentukan seberapa jauh penempatan tenaga pendidik, dan kompetensi yang dikorelasikan dengan kebutuhan penyelenggaraan pendidikan yang bermutu. Dengan kata lain yang menjadi permasalahan umum dalam penelitian ini adalah, apakah penempatan tenaga pendidikan (distribusi), standar kompetensi guru sudah sesuai dengan kebutuhan peningkatan kualitas pendidikan di Kabupaten Kutai Kartanegara?’.

Tujuan yang ingin dicapai dalam Penelitian ini adalah; (1). Untuk mengevaluasi apakah penempatan tenaga pendidikan (distribusi) sesuai dengan kompetensi guru terhadap mata pelajaran ?. (2). Untuk menganalisis bagaimanakah standar kualifikasi (kompetensi) tenaga pendidikan yang tersedia di Kabupaten Kutai Kartanegara (3). Untuk mengevaluasi standar kualitas pendidikan (mutu) yang telah dicapai di Kabupaten Kutai Kartanegara. Sedangkan manfaat yang diharapkan menjadi input bagi stakeholder dan Pemerintah Kabupaten Kutai Kartanegara dalam menetapkan berbagai kebijakan sektor pendidikan.

Landasan yuridis tentang monitoring dan evaluasi pendidikan yang digunakan sebagai dasar pelaksanaan pemantauan dan evaluasi adalah: 1). Undang-Undang No. 20 Tahun 2003 tentang Sistem Pendidikan Nasional; 2). Undang-Undang No. 32 Tahun 2004 tentang Pemerintah Daerah; 3). Peraturan Pemerintah No. 19 Tahun 2005 tentang Standar Nasional Pendidikan; dan 4). Berbagai regulasi terkait lainnya.
Monitoring dan evaluasi yang dilakukan hendaknya berdasarkan prinsip-prinsip sebagai berikut: (1). Kejelasan tujuan yang diperoleh dari monitoring dan evaluasi; (2). Pelaksanaan dilakukan secara objektif; (3). Dilakukan oleh Tim yang memahami konsep, teori dan proses serta berpengalaman dalam kontek evaluasi; (4). Dilakukan secara transparan, sehingga hasilnya dapat dilaporkan kepada stakeholders; (5). Melibatkan berbagai pihak yang dipandang berkepentingan secara proaktif (partisipatif); (6). Pelaksanaan dapat dipertanggung jawabkan secara internal dan eksternal (akuntabel); (7). Menggambarkan secara utuh kondisi dan situasi sasaran pemantauan dan evaluasi (komperehensif); (8). Pelaksanaan dilakukan sesuai jadwal yang telah ditetapkan secara tepat; (9). Dilaksanakan secara berkala dan berkelanjutan; (10). Berbasis indikator kinerja, yaitu kriteria/indikator yang dikembangkan berdasarkan tiga tema kebijakan Depdiknas; (11). Efektif dan efisien, artinya target pementauan dan evaluasi dicapai dengan menggunakan sumber daya terbatas dan sesuai dengan perencanaan.

Berbicara mutu pendidikan merupakan salah satu masalah "serius" yang dihadapi Pemerintah Daerah, bahkan sekolah sekalipun. Ini dikarenakan rnutu sebagai salah satu output, mutu pendidikan merupakan suatu proses (belajar mengajar) yang komplek dan panjang dengan melibatkan semua komponen pendidikan secara optimal dan sinergis. Toffler dalam Tirtarahardja dan Sula (2005) menganalogikan sekolah dengan sebuah pabrik, dimana pendidikan sebagai suatu system yang merupakan proses mekanisme bahan mentah (raw input) berupa serta didik dan setelah melalui tahapan "proses" menghasilkan keluaran (instrumental input) dan kondisi lingkungan (environmental input) yang mendukung bagi terjaminnya proses pendidikan (belajar mengajar). Lebih lanjut, Tirtaraharja dan Sula (2005) memaparkan bahwa instrumental input meliputi: tenaga guru dan non-guru, kurikulum, anggaran, administrasi dan sarana/prasarana. Sedangkan environmental input meliputi: sosial budaya, kependudukan, keamanan, politik, ekonomi dan lain-lain.

Dari sekian banyak komponen dalam proses belajar mengajar, aspek guru/tenaga pendidikan menarik untuk dikaji lebih mendalam. Ini dikarenakan guru sebagai "agen" yang mengubah kognitif, afektif maupun psikomotor peserta didik. Oleh sebab itu peranan guru sebagai pengelola proses belajar-mengajar sangat menentukan kualitas proses belajar, yang pada akhirnya akan bermuara pada kualitas hasil belajar dalam hal ini adalah output pendidikan. Untuk memenuhi kebutuhan Tenaga Pendidikan yang efektif dan efesien bagi pengembangan dunia pendidikan secara ideal sulit diharapkan, hal ini disebabkan oleh kemampuan anggaran belanja Negara. Disamping itu, standar keahlian dan kompetensi SDM yang belum terdata 
dengan baik oleh pemerintah menjadi masalah yang krusial dalam menetapkan kebutuhan formasi tenaga pendidikan. Meskipun pemerintah telah mencoba membuat pedoman menetapkan formasi kebutuhan guru, dan PNS Daerah yang diatur dalam UndangUndang No. 32 Tahun ,2004 tentang Pemerintahan Daerah. Adapun mekanisme penyampaian penetapan formasi PNS dan Guru dapat dilihat pada Tabel 1. mendaftarkan diri, mengikuti test dan setelah dinyatakan lulus barn bekerja sebagai tenaga pendidikan di sekolah dimana yang bersangkutan ditugaskan. Kedua, calon pendidik mendahului aktivitasnya bekerja sebagai tenaga pendidik di sekolah tertentu dengan status pegawai honorer, mendaftarkan diri sebagai calon tenaga pendidikan jika ada proses seleksi yang dilakukan oleh pihak

Tabel 1: Proses Pengadaan Tenaga Kependidikan

\begin{tabular}{|c|c|c|c|}
\hline No. & $\begin{array}{r}\text { Unit Kerja } \\
\text { enetapan Formasi }\end{array}$ & Kegiatan/Peran & Waktu (Dapat Berubah) \\
\hline 1. & $\begin{array}{l}\text { Menteri } \\
\text { Pemberdayaan } \\
\text { Aparatur Negara } \\
\text { (MENPAN) }\end{array}$ & $\begin{array}{l}\text { Menerima dan menelaah serta } \\
\text { memberikan pertimbangan atas usulan } \\
\text { Gubemur } \\
\text { Menyampaikan surat Hasil } \\
\text { Pertimbangan atas usulan Gubemur } \\
\text { kepada Bupati/Walikota }\end{array}$ & $\begin{array}{l}\text { Juli pada t0 untuk rencana ( } \\
\text { t0 } 1 \text { ) } \\
\text { Juli pada t0 untuk rencana ( t0 } \\
+1 \text { ) }\end{array}$ \\
\hline 2. & $\begin{array}{l}\text { Bupati/Wali Kota } \\
\text { Termasuk Bagian } \\
\text { Kepegawaian } \\
\text { Daerah) }\end{array}$ & $\begin{array}{l}\text { MeneriSurat Keputusan hasil } \\
\text { pertimbangan dari MENPAN } \\
\text { Membahas alokasi formasi CPNS } \\
\text { (Dalam hal ini Guru) dengan masing- } \\
\text { masing Unit Kerjanya } \\
\text { Menetapkan alokasi formasi CPNS } \\
\text { Mendistribusikan formasi ke setiap Unit } \\
\text { Kerjannya }\end{array}$ & $\begin{array}{l}\text { Agustus pada t0 untuk } \\
\text { rencana }(\mathrm{t} 0+1) \\
\text { September pada t0 untuk } \\
\text { rencana }(\mathrm{t} 0+1) \\
\text { September pada t0 untuk } \\
\text { rencana }(\mathrm{t} 0+1) \\
\text { September pada t0 untuk } \\
\text { rencana }(\mathrm{t} 0+1)\end{array}$ \\
\hline 3. & $\begin{array}{l}\text { Dinas Pendidikan } \\
\text { Provinsi dan } \\
\text { Kabupaten/Kota }\end{array}$ & $\begin{array}{l}\text { Menerima alokasi formasi CPNS } \\
\text { Mengalokasikan tambahan formasi } \\
\text { CPNS (jika ada) }\end{array}$ & $\begin{array}{l}\text { Oktober pada t0 untuk rencana } \\
(\mathrm{t} 0+1)\end{array}$ \\
\hline
\end{tabular}

Sumber : UU No. 32 Tahun 2004 dan Pedoman Pengadaan PNS 2005

Keterangan : $\quad$ t0 = Rencana tahun berjalan

$$
(\mathrm{t} 0+1)=\text { Rencana tahun yang akan dating }
$$

Dalam Proses Rekrutmen tenaga kependidikan, masalah tenaga pendidikan, guru adalah bagian yang tidak terpisahkan dari profesinya untuk menjalankan fungsi pendidikan kepada masyarakat secara formal yang secara tidak langsung merupakan beban yang harus ditanggung oleh pemerintah. Karena itu proses dan penetapan rekrutmen tenaga pendidikan adalah tanggungjawab pemerintah yang dilaksanakan melalui unit kerja yang ditunjuk untuk menjalankan proses tersebut.

Konsep Rekrutmen menurut Sondang P. Siagian (2009) adalah proses mencari, menemukan dan menarik para pelamar yang dapat dipekerjakan dalam dan oleh suatu organisasi". Dalam pengertian ini, rekruetmen harus dimulai dari mencari pelamar yang dapat dilakukan melalui proses yang beragam seperti memasang pengumuman di media tertentu, menugaskan institusi tingkat bawah, pendekatan persuasif atau mengagendakan rekrutmen setiap waktu secara continue sehingga berbagai pihak dapat menyiapkan diri sebelumnya dan segera melamar pada saat tiba masa waktunya.

Dalam persoalan rekrutmen tenaga pendidikan, maka proses yang selama ini dilakukan melalui dua bentuk, pertama, calon pendidik harus yang berkompeten. Aktivitas sebelumnya sebagai tenaga pendidikan honorer dijadikan referensi mendapatkan prioritas kelulusan.

Menelaah pengertian umum tentang distribusi Tenaga Pendidikan/Guru akan diketahui adanya dua kutub yang saling berlawanan yaitu distribusi absolut tidak merata (absolute inequality) dan distribusi absolut yang merata (absolute equality). Distribusi absolut yang tidak merata adalah pola distribusi yang sangat timpang dan hanya mengelompok pada satu golongan atau bagian saja. Kemudian distribusi absolut yang merata adalah pola distribusi yang mana setiap elemen atau bagian menerima bagian yang sama.

Dalam masalah distribusi ini dan konteksnya dengan tenaga pendidikan, peraturan perundangundangan menggariskan bahwa distribusi dalam pengertiannya adalah sebagai penempatan tenaga pendidikan yang merupakan rangkaian proses pemenuhan tenaga pendidikan dari perencanaan kebutuhan, formasi, pengadaan, pengangkatan sampai dengan penempatan, mutasi dan pemberhentian.

Penempatan adalah suatu kebijakan yang diambil oleh pimpinan suatu instansi atau bagian 
kepegawaian untuk menentukan seseorang pegawai masih tetap atau ditempatkan pada suatu posisi atau jabatan tertentu berdasarkan pertimbangan keahlian, keterampilan dan kualifikasi tertentu (Sulistiani dan Rosidah, 2003). Menurut UU No. 14 Tahun 2005 tentang Guru dan Dosen mengatakan bahwa "penempatan guru dilakukan secara obyektif dan transparan sesuai dengan peraturan perundangundangan, dimana penempatan guru pada satuan pendidikan diatur dengan Peraturan Pemerintah. Selain itu penempatan guru yang diselenggarakan swasta dilakukan oleh penyelenggara pendidikan atau satuan pendidikan yang bersangkutan berdasarkan perjanjian kerja atau kesepakatan kerja bersama".

Sedangkan pada pasal 28 Undang-Undang No. 14 Tahun 2005 mengatakan bahwa guru yang diangkat oleh pemerintah atau pemerintah daerah dapat dipindahtugaskan antar provinsi, antar kabupaten/kota, antar kecamatan maupun antar satuan pendidikan karena alasan kebutuhan satuan pendidikan dan/atau mutasi. Selain itu guru yang diangkat tersebut dapat pula mengajukan permohonan pindah tugas, baik antar provinsi, antar kabupaten/kota, antar kecamatan maupun antar satuan pendidikan karena alasan kebutuhan satuan pendidikan sesuai peraturan perundang-undangan.

\section{METODE}

Metode yang digunakan dalam penelitian ini adalah melalui metode Penelitian survei yang merupakan salah satu metode yang bertujuan untuk memperoleh gambaran umum tentang karakteristik populasi. Survei juga dapat dilakukan untuk mengumpulkan data terkait sikap, nilai, kepercayaan, pendapat, pendirian, keinginan, cita-cita, sikap, dan prilaku. Menurut Masri Singarimbun (2008:12) Dalam survai, informasi dikumpulkan dari responden dengan menggunakan kuesioner. Umumnya, pengertian survai dibatasi pada penelitian yang datanya dikumpulkan dari sampel atas populasi untuk mewakili seluruh populasi. Ini berbeda dengan sensus yang informasinya dikumpulkan dari seluruh populasi. Dengan demikian penelitian survai adalah "penelitian yang mengambil sampel dari satu populasi dan menggunakan kuesioner sebagai alat pengumpulan data yang pokok.

Sedangkan Penelitian survei menurut Suhartono (2000:54) mempunyai dua (2) tujuan; pertama untuk memberikan gambaran tentang sesuatu (survey deskriptif), dan kedua melakukan analisis (suvey analitik).

Sample dan Responden; Populasi studi adalah kepala sekolah dan guru SD, SMP dan SMA berstatus PNS dan swasta. Sample dibagi kedalam tiga wilayah, yakni: kawasan pantai (zona pantai), kawasan tengah (zona tengah) dan kawasan hulu (zona hulu). Penarikan sample diawali dengan penentuan sample kecamatan dan pada setiap sekolah sample ditentukan $30 \%$ responden sekolah per kecamatan, sedangkan lokus Penelitian dilakukan di 8 kecamatan dengan jangka waktu selama 3 bulan.

Pengumpulan data dilakukan dengan menggunakan kuisioner terhadap responden kepala sekolah dan guru, dimana setiap kecamatan diperoleh responden sebanyak $30 \%$ dari jumlah sekolah yang ada. Data tentang mutu guru yang dijaring dalam studi ini adalah: (a). Kompetensi guru (teacher competence) yang meliputi, knowledges dan skills. (b). Performance guru (teacher Performance) personal qualities. Selanjutnya data tentang factorfaktor yang mempengaruhi mutu guru yang dijaring adalah: (a). Karakteristik guru (instructor characteristics), (b). Karakteristik sekolah (course characteristics) dan (c). Karaktreristik siswa (student characteristics).

Analisis data yang dilakukan meliputi analisis deskrifptif dan inferensial. Metode ini dilakukan terhadap system analisis terhadap Quisioner yang beragam bentuk pertanyaan dan kecenderungan jawaban yang akan diberikan responden. Pendekatan lain dapat dilakukan dengan cara menerapkan alat analisis yang berbeda dari setiap jawaban responden terhadap pertanyaan quisioner.

\section{HASIL DAN PEMBAHASAN}

Deskripsi penempatan guru di Kutai Kartanegaran menyatakan bahwa rata-rata guru yang diterima/diangkat sebagai PNS, (94,12\%) penempatannya diatur oleh Pemerintah Kabupaten (BKD). Dimana para guru yang ditempatkan tersebut $(68,50 \%)$ menyatakan bahwa sekolah yang menjadi tempat mereka bertugas sesuai dengan harapan mereka, dan $(31,50 \%)$ menyatakan tidak sesuai dengan harapan. Selanjutnya responden menyatakan bahwa pendistribusian mata pelajaran yang dilakukan sekolah kepada guru sesuai dengan jurusan atau bidang mereka (80,50\%) sedangkan yang tidak sesuai dengan jurusan/bidang mereka $(19,50 \%)$. Sebagian besar jurusan/bidang pendidikan para guru adalah umum $(36,60 \%)$ seni rupa $(36,60 \%)$ agama islam $(16,70 \%)$ teknik pendidikan $(6,60 \%)$ dan matematika $(3,30 \%)$.

Untuk mengatasi ketidaksesuaian mata pelajaran yang dibebankan kepada mereka berbagai cara yang telah dilakukan, diantaranya mengikuti pelatihan (40\%); belajar sendiri $(24,40 \%)$; bertanya pada rekan (31,10\%); dan lainnya (4,40\%). Walaupun terdapat ketidaksesuaian terhadap mata pelajaran tersebut, dan, para guru berupaya meningkatkan kemampuannya sehingga menyukai mata pelajaran yang menjadi tanggung jawabnya, maka $(89,47 \%)$ rata-rata responden berpendapat bahwa mereka menyenangi mata pelajaran tersebut. Ketidaksesuaian mata pelajaran dengan jurusan/bidang keahlian guru di atas disebabkan oleh 
beberapa faktor, diantaranya karena sekolah kekurangan guru (30,50\%); kekurangan guru pada matapelajaran tertentu $(49,10 \%)$; adanya sekolah yang kelebihan guru terhadap matapelajaran tertentu $(15,30 \%)$; dan ditentukan langsung oleh Diknas $(5,08 \%)$. Penjelasan tersebuta dapat dilihat pada Tabel 2 .
$(21,38 \%)$, pemeriksaan administrasi kelas $(25,19 \%)$, pemeriksaan satuan pelajaran $(16,79 \%)$, diklat $(23,66 \%)$, promosi jabatan $(11,45 \%)$, dan pembinaan lainnya $(1,52 \%)$. Pembinaan yang dilakukan tersebut $(71,42 \%)$ dilaksanakan oleh pengawas sekolah sedangkan (28,57\%), dilakukan oleh pihak lain termasuk kepala sekolah, dimana pembinaan yang

Tabel 2. Jawaban Guru Terhadap Penempatan Guru

Kesesuaian sekolah yang dipilih:

Instansi yang menempatkan saudara sebagai guru di sekolah

\begin{tabular}{lc} 
a. Kepala/Sekretariat Pemkab & $17,6 \%$ \\
b. Dinas Pendidikan & $44,1 \%$ \\
c. Badan Kepegawaian Daerah & $32,35 \%$ \\
d. Lainnya ............ & $5,88 \%$ \\
\hline
\end{tabular}

Keadaan sekolah sesuai dengan keinginan ketika mengajukan permohonan

\begin{tabular}{ll} 
a. Ya sesuai & $68,5 \%$ \\
b. Tidak sesuai & $31,5 \%$ \\
\hline
\end{tabular}

Kesesuaian jurusan dengan mata pelajaran yang diajarkan:

Kesesuaian jurusan yang dimiliki guru dengan materi yang ditugaskan

\begin{tabular}{ll} 
a. Ya telah sesuai & $80,5 \%$ \\
b. Tidak sesuai & $19,5 \%$ \\
\hline
\end{tabular}

Apakah yang dilakukan untuk mengatasi ketidaksesuaian

\begin{tabular}{lc} 
a. Mengikuti pelatihan & $40 \%$ \\
b. Belajar sendiri & $24,4 \%$ \\
c. Bertanya pada yang dianggap ahli & $31,1 \%$ \\
d. Lainnya perpaduan a,b,c & $4,4 \%$ \\
\hline
\end{tabular}

\begin{tabular}{lc} 
Apakah saudara senang mengajar matapelajaran sekarang \\
\hline a. Senang & $89,47 \%$ \\
b. Kurang senang & $8,77 \%$ \\
c. Tidak senang & $1,75 \%$ \\
\hline & \\
\hline & \\
\hline Apakah ada guru yang tidak sesuai antara jurusan dengan materi ajar & $61,6 \%$ \\
b. Ya Tidak & $38,4 \%$ \\
\hline
\end{tabular}

Didalam dunia pendidikan sangat diperlukan spesialisasi pada bidang studi/mata pelajaran tertentu, oleh karenanya para guru (pendidik) selalu diberi mata pelajaran utama minimal sesuai dengan jurusan pendidikannnya, rata-rata responden (guru) menyatakan bahwa $(73,10 \%)$ mereka hanya mengajar matapelajaran utama yang menjadi tugas dan tanggung jawabnya, sementara $(26,80 \%)$ selain mengajar mata pelajaran utama juga memberikan pelajaran mata pelajaran lain.

Dalam konteks meningkatkan kapasitas guru dalam menyampaikan materi pelajaran kepada anak didik, sesuai dengan peraturan maka para guru harus melakukan beberapa kegiatan. Rata-rata responden (kepala sekolah) berpendapat bahwa untuk meningkatkan kemampuan dan kualitas guru yang dipimpinnya harus dilakukan pembinaan secara kontinyu, diantara melalui penilaian aktivitas PBM dilakukan oleh pihak lain (89\%) dilakukan oleh Dinas Pendidikan.

Pembinaan yang sering dilakukan oleh pengawas sekolah maupun pihak lain adalah peningkatan kemampuan para guru seperti: metode mengajar $(15,30 \%)$, penguasaan materi $(20,40 \%)$, pengelolaan PBM $(16,32 \%)$, penyusuan satuan pelajaran $(11,22 \%)$, membuat alat peraga $(10,20 \%)$; menggunakan alat peraga $(12,24 \%)$, dan memahami peserta didik $(14,28 \%)$. Dari unsur pembinaan ini dapat diketahui bahwa berbagai upaya yang dilakukan oleh pengawas sekolah dan pihak lain (pemerintah dan kepala sekolah) guna meningkatkan Kemampuan guru dengan harapan terdapat peningkatan kualitas pendidikan di Kabupaten Kutai Kartanegara. Hal tersebut ditunjukkan pada Tabel 3.

Profesi guru merupakan bidang pekerjaan yang sangat berat, dimana seorang pendidik (guru) 
Tabel 3. Jawaban Terhadap Pembinaan Kapasitas Guru

Bentuk pembinaan yang dilakukan terhadap guru-guru

$\begin{array}{lc}\text { a. Menilai aktivitas PBM guru } & 21,38 \% \\ \text { b. Memeriksa administrasi kelas } & 25,19 \% \\ \text { c. Memeriksa satuan pelajaran } & 16,79 \% \\ \text { d. Mengikutsertakan guru dalam penataran/diklat } & 23,66 \% \\ \text { e. Mempromosikan kejabatan } & 11,45 \% \\ \text { f. Lainnya } & 1,52 \%\end{array}$

Pembinaan Pengawas terhadap sekolah untuk kepentingan
a. Belum Pernah
$28,57 \%$
b. Ya Pernah
$71,42 \%$

\begin{tabular}{ll} 
Jika Pernah, Apa yang dilakukan pengawas pada kunjungan pembinaan \\
\hline a. Mengomentari PBM & $25,58 \%$ \\
b. Memeriksa administrasi kesiapan mengajar guru & $32,55 \%$ \\
c. Memberikan tanggapan tentang kesiapan mengajar guru & $27,90 \%$ \\
d. Mendemonstrasikan cara melaksanakan PBM & $10,46 \%$ \\
e. Lainnya & $3,48 \%$
\end{tabular}

Selain Kepsek dan Pengawas, Pihak mana yang pernah melakukan pembinaan terhadap guru
a. Dinas Kecamatan
$48,38 \%$
b. Dinas Pendidikan Kabupaten
$41,93 \%$
c. Lainnya Dept Transmigrasi, LSM
$9,67 \%$

Pembinaan apa yang penting dilakukan terhadap guru

a. Kemampuan terhadap metode mengajar $\quad 15,30 \%$

b. Kemampuan penguasaan materi pelajaran $\quad 20,40 \%$

c. Kemampuan mengelola PBM 16,32\%

d. Kemampuan menyusun Satuan Pelajaran $\quad 11,22 \%$

e. Kemampuan membuat alat peraga $\quad 10,20 \%$

f. Kemampuan menggunakan alat peraga di kelas $\quad 12,24 \%$

g. Kemampuan memahami peserta didik $14,28 \%$

dituntut memiliki kemampuan dan keahlian sesuai tuntutan profesinya. Sudah menjadi ungkapan umum bahwa "guru merupakan ujung tombak pembangunan intelektual bangsa". Disamping itu guru menjadi suri tauladan bagi anak didiknya, oleh karena itu para orang tua memberikan kepercayaan kepada guru untuk memberikan pendidikan kepada anak-anak mereka.

Standar Tingkat Pendidikan dan Jurusan; Dari 240 responden guru diperoleh hasil penelitian yang berkaitan dengan pendidikan terakhir/tertinggi yaitu PGA $(2,32 \%)$, SPG $(13,95 \%)$, SMA $(3,48 \%)$, D2 Pendidikan (30,23\%), D3 Pendidikan (3,48\%), Sarjana Muda Pendidikan $(1,16 \%)$, Sarjana Pendidikan (32,55\%), Sarjana Non Pendidikan $(4,65 \%)$, dan Sarjana IAIN $(8,13 \%)$. Dari tingkat pendidikan yang telah ditempuh oleh para guru tersebut, rata-rata responden memiliki bidang keahlian (spesialisasi) pada pelajaran Matematika (7,81\%), Biologi (6,25\%), Fisika (4,68\%), Kesejahteraan Keluarga (1,56\%), Mesin (1,56\%), Sosiologi (1,56\%), Bahasa Indonesia $(6,25 \%)$, Bahasa Inggris (6,25\%), Ekonomi (4,68\%),
Elektronik (1,56\%), Seni (1,56\%), Agama (17,18\%), dan (IPS, IPS, Olahraga) sebanyak $(39,06 \%)$. Jika dilihat dari pendidikan terakhir/tertinggi yang ditempuh oleh responden dapat dikatakan bahwa rata-rata guru di Kabupaten Kutai Kartanegara berpendidikan cukup tinggi, tetapi masih sedikit yang memiliki jurusan atau spesialisasi pada bidang mata pelajaran yang spesifik dan benar-benar menguasai bidang studi/pelajaran yang dipegangnya. Jawaban resmponden mengenai hal tersebut dapa dilihat pada Tabel 4.

Standar tingkat pengalaman mengajar; Ratarata responden (guru) menyatakan bahwa pengalaman mengajar para guru yang bekerja di Kabupaten Kutai Kartanegara cukup lama, yaitu kurang dari 1 tahun hanya $(1,58 \%)$, ls/d 5 tahun $(19,04 \%), 5$ s/d 10 tahun $(9,52 \%)$, lebih dari 10 tahun $(69,84 \%)$. Dengan rata-rata pengalaman mengajar yang cukup lama tersebut tentunya guru dalam melaksanakan tugasnya akan lebih (profesional), lebih-lebih hal ini didukung dengan spesialisasi guru dalam memegang suatu mata pelajaran tertentu dalam jangka waktu yang lama, rata-rata responden 
Tabel 4. Jawahan Responden Terhadap Tingkat Pendidikan dan Jurusan

\begin{tabular}{|c|c|}
\hline Pendidikan Terakhir & $\%$ \\
\hline a. PGA & 2,32 \\
\hline b. SPG & 13,95 \\
\hline c. SMA & 3,48 \\
\hline d. D1 Non Pendidikan & 0 \\
\hline e. D1 Pendidikan & 0 \\
\hline f. D2 Non Pendidikan & 0 \\
\hline g. D2 Pendidikan & 30,23 \\
\hline h. D3 Non Pendidikan & 0 \\
\hline i. D3 Pendidikan & 3,48 \\
\hline j. Sarjana Muda Non Pendidikan & 0 \\
\hline k. Sarjana Muda Pendidikan & 1,16 \\
\hline 1. Sarjana Muda IAIN & 0 \\
\hline m. Sarjana Pendidikan & 32,55 \\
\hline n. Sarjana Non Pendidikan & 4,65 \\
\hline o. Sarjana IAIN & 8,13 \\
\hline p. Lainnya & 0 \\
\hline
\end{tabular}

(guru) menyatakan bahwa lamanya mata pelajaran terakhir yang mereka pegang kurang dari 1 tahun $(1,81 \%), 1 \mathrm{~s} / \mathrm{d} 5$ tahun $(38,18 \%), 5 \mathrm{~s} / \mathrm{d} 10$ tahun $(38,18 \%)$, lebih dari 10 tahun $(21,81 \%)$. Jawaban terhdap pengalaman mengajar guru dapat dilihat pada Tabel 5 . dukungan administrasi dan sarana prasarana dan sumber daya lainnya serta penciptaan suasana yang kondusif.

Ada dua faktor yang dapat menjelaskan mengapa upaya perbaikan mutu pendidikan selama ini kurang atau tidak berhasil. Pertama, strategi

Tabel 5. Jawaban terhadap pengalaman mengajar guru

\begin{tabular}{lcc}
\hline \multicolumn{1}{c}{ Lamanya waktu menjadi guru } & $\mathbf{\%}$ \\
\hline a. Kurang dari 1 Tahun & 1,58 \\
b. 1 s/d 5 Tahun & 19,04 \\
c. Lebih dari 5 s/d 10 Tahun & 9,52 \\
d. Lebih dari 10 Tahun & 69,84 \\
\hline \multicolumn{2}{c}{ Lamanya mengajar mata pelajaran terakhir } \\
\hline \multicolumn{2}{c}{$\%$} \\
\hline e. Kurang dari 1 Tahun & 1,81 \\
f. 1 s/d 5 Tahun & 38,18 \\
g. Lebih dari 5 s/d 10 Tahun & 38,18 \\
h. Lebih dari 10 Tahun & 21,81 \\
\hline
\end{tabular}

\begin{abstract}
Dalam melaksanakan suatu kegiatan/pekerjaan seseorang harus mengenal dengan baik lingkungan dimana dia berada atau melaksanakan tugas, hal ini dibutuhkan untuk menumbuhkan ketenangan dan kenyamanan dalam bekerja. Untuk mengenal lingkungan kerja dengan baik diperlukan waktu beradaptasi yang cukup lama, begitu pula para guru dalam melaksanakan tugas dan tanggung jawabnya harus mengenal baik lingkungannya.
\end{abstract}

\section{Kebijakan Strategis dalam peningkatan mutu pendidikan}

Dalam konteks pendidikan pengertian mutu, dalam hal ini mengacu pada proses pendidikan dan hasil pendidikan. Dalam "proses pendidikan" yang bermutu terlibat berbagai input, seperti; bahan ajar (kognitif, afektif, atau psikomotorik), metodologi (bervariasi sesuai kemampuan guru), saran sekolah, pembangunan pendidikan selama ini lebih bersifat input oriented. Strategi yang demikian lebih bersandar kepada asumsi bahwa bilamana semua input pendidikan telah dipenuhi, seperti penyediaan buku-buku (materi ajar) dan alat belajar lainnya, penyediaan sarana pendidikan, pelatihan guru dan tenaga kependidikan lainnya, maka secara otomatis lembaga pendidikan (sekolah) akan dapat menghasilkan output (keluaran) yang bermutu sebagai mana yang diharapkan. Kedua, pengelolaan pendidikan selama ini lebih bersifat macro-oriented, diatur oleh jajaran birokrasi ditingkat pusat. Akibatnya, banyak faktor yang diproyeksikan ditingkat makro (pusat) tidak terjadi atau tidak berjalan sebagaimana mestinya di tingkat mikro (sekolah). Atau dengan ingkat dapat dikatakan bahwa kompleksitas permasalahan pendidikan, seringkali tidak terpikirkan holistik oleh birokrat. 
Dengan demikian pembangunan pendidikan bukan hanya terfokus pada penyediaan faktor input pendidikan tetapi juga harus lebih memperhatikan faktor proses pendidikan. Input pendidikan merupakan hal yang mutlak harus ada dalam batasbatas tertentu tetapi tidak menjadi jaminan dapat secara otomatis meningkatkan mutu pendidikan (school resources are necessary but not sufficient condition to improve student achievement). Pemikiran ini telah mendorong munculnya pendekatan baru, yakni pengelolaan peningkatan mutu pendidikan dimasa mendatang harus berbasis sekolah sebagai institusi paling depan dalam kegiatan pendidikan. Pendekatan ini, kemudian dikenal dengan manajemen peningkatan mutu pendidika berbasis sekolah (School Based Quality Management) atau dalam nuansa yang lebih bersifat pembangunan (developmental) disebut School Based Quality Improvement (Umaedi; 1999).

Konsep yang menawarkan kerjasama yang erat antara sekolah, masyarakat dan pemerintah dengan tanggung jawabnya masing-masing berkembang didasarkan kepada suatu keinginan pemberian kemandirian kepada sekolah untuk ikut terlibat secara aktif dan dinamis dalam rangka proses peningkatan kualitas pendidikan melalui pengelolaan sumber daya sekolah. Sekolah harus mampu menterjemahkan dan menangkap esensi kebijakan makro pendidikan serta memahami kondisi lingkunganya (kelebihan dan kekurangannya) untuk kemudian melaui proses perencanaan, sekolah harus memformulasikan kedalam kebijakan mikro dalam bentuk program-program prioritas yang harus dilaksanakan dan dievaluasi sesuai dengan visi dan misinya masing-masing.

Sebagai pelaksana dilapangan, guru sebenamya memiliki peran yang sangat strategis dalam menyelesaikan persoalan-persoalan kebangsaan yang sering dikaitkan dengan dunia pendidikan. Kurikulum Berbasis Kompetensi (KBK) bisa dianggap sebagai salah satu solusi yang cukup cerdas. Sebab, KBK menuntut guru agar dapat mengelola proses belajar dengan lebih kreatif, dinamis, dan progresif. Hanya saja, hal ini membutuhkan kompetensi guru yang sangat mendasar, salah satunya adalah kompetensi intelektual. Guru sering menjadi sorotan dan dianggap sebagai pihak yang paling bertanggung jawab bagi kegagalan berbagai program pendidikan. Berbagai program tersebut tidak dapat diimplementasikan secara baik di lapangan. Salah satunya adalah rendahnya kapasitas intelektual guru. Hal ini disebabkan oleh kesulitan guru mengakses informasi tentang wacana pendidikan terbaru yang melatarbelakangi perubahan kebijakan dan program pendidikan.

Permasalahannya adalah tidak adanya media yang dapat digunakan guru untuk memperkaya diri dengan wacana dan diskursus pendidikan kontemporer. Akibatnya, apa yang dilakukan guru menjadi out of date dan monoton. Sebagian guru hanya lebih banyak mengetahui wacana-wacana tersebut dari penataran yang diadakan oleh pemerintah yang efektivitasnya masih diragukan. Dengan demikian, tampaknya perlu dikembangkan sebuah program yang dapat meningkatkan intelektualitas guru. Program semacam ini sangat penting mengingat percepatan perkembangan dunia kependidikan beberapa waktu terakhir ini tidak bisa dilepaskan dari dunia buku dan teknologi informasi.

Peran Pemerintah dalam peningkatan mutu pendidikan tentu sangat besar, beberapa kebijakan strategis yang disusun dalam rangka memperluas pemerataan dan akses pendidikan adalah sebagai berikut:

1. Memperluas akses pendidikan bagi anak usia 0-6 tahun, untuk memiliki kesempatan tumbuh dan berkembang secara optimal sesuai potensi yang dimiliki dan tahap perkembangannya agar memiliki kesiapan dalam mengikuti pendidikan sekolah dasar.

2. Menghapus hambatan biaya (cost barriers) melalui pemberian Bantuan Operasional Sekolah (BOS) bagi semua siswa pada jenjang pendidikan dasar (dikdas) baik pada sekolah umum maupun madrasah yang dimiliki oleh pemerintah atau masyarakat. yang besamya dihitung berdasarkan unit cost per siswa dikalikan dengan jumlah seluruh siswa pada jenjang tersebut. Disamping itu, dilakukan kebijakan pemberian subsidi biaya personal terutama bagi siswanya berasal dari keluarga miskin pada jenjang dikdas melalui pemanfaatan BOS untuk tujuan tersebut.

3. Membentuk "SD-SMP Satu Atap" bagi daerah terpencil yang berpenduduk jarang dan terpencar, dengan menambahkan ruang belajar SMP di SD untuk menyelenggarakan program pendidikan SMP bagi lulusannya. Untuk mengatasi kesulitan tenaga pengajar dalam kebijakan ini dapat dilakukan dengan memanfaatkan guru SD untuk mengajar di SMP pada beberapa mata pelajaran yang relevan atau dengan meningkatkan kompetensi guru sehingga dapat mengajar di SMP.

4. Memperluas akses pendidikan bagi anak usia sekolah 7-15 tahun, yang tidak/belum terlayani dijalur pendidikan formal untuk memiliki kesempatan mendapatkan layanan pendidikan di jalur nonformal maupun program pendidikan terpadu/inklusif bagi anak-anak yang berkebutuhan khusus terutama untuk daerahdaerah yang tidak tersedia layanan pendidikan khusus luar biasa. Disamping itu, untuk memperluas akses bagi penduduk usia 13-15 tahun dikembangkan SMP Terbuka melalui optimalisasi daya tampung SMP Terbuka model maupun melalui model pendidikan alternatif yang inovatif.

5. Memperluas akses bagi penduduk buta aksara usia 15 tahun ke atas untuk memiliki kesempatan 
mendapatkan layanan pendidikan keaksaraan melalui jalur pendidikan nonformal. Perluasan kesempatan bagi penduduk buta aksara dilakukan dengan menjalin berbagai kerjasama dengan stakeholder pendidikan.

6. Memfasilitasi peran serta masyarakat dalam memperluas akses SMA, khususnya pada daerahdaerah yang memiliki lulusan SMP cukup besar. Disisi lain dikembangkan SMA terpadu, yaitu pendidikan yang menyelenggarakan pendidikan umum dan kejuruan dalam satu satuan pendidikan.

7. Memperluas akses terhadap pendidikan di SMK sesuai kebutuhan dan keunggulan lokal. Perluasan SMK ini dilaksanakan melalui penambahan program pendidikan kejuruan yang lebih fleksibel sesuai untutan pasar kerja yang berkembang.

8. Memperluas kesempatan belajar sepanjang hayat bagi penduduk dewasa yang ingin meningkatkan pengetahuan, keterampilan, dan kecakapan hidup yang relevan dengan kebutuhan masyarakat melalui program-program pendidikan berkelanjutan.

9. Memperhatikan secara khusus kesetaraan gender, pendidikan untuk layanan khusus di daerah terpencil dan daerah tertinggal, daerah konflik, perbatasan, dan lain-lain, serta mengimplementasikannya dalam berbagai program secara terpadu.

10. Melaksanakan Komunikasi, Informasi, Edukasi (KIE), serta advokasi kepada masyarakat agar keluarga makin sadar akan pentingnya pendidikan serta siap mengirim anak-anaknya ke sekolah dan/atau mempertahankan anaknya untuk tetap bersekolah.

11. Memanfaatkan secara optimal sarana radio, televisi, komputer dan perangkat ICT lainnya untuk digunakan sebagai media pembelajaran dan untuk pendidikan jarak jauh sebagai sarana belajar altematif selain menggunakan modul atau tutorial, terutama bagi daerah terpencil dan mengalami hambatan dalam transportasi.

Upaya peningkatan mutu dan relevansi pendidikan secara berkelanjutan akan dilakukan oleh pemerintah, pemerintah daerah, dan satuan pendidikan secara terpadu. Manajemen mutu tersebut dilaksanakan melalui kebijakan strategis sebagai berikut:

1. Mengembangkan dan menetapkan Standar Nasional Pendidikan sesuai dengan PPSNP No. 19 tahun 2005, sebagai dasar melaksanakan penilaian pendidikan, peningkatan kapasitas pengelolaan pendidikan, peningkatan sumberdaya pendidikan, akreditasi satuan dan program pendidikan, serta upaya penjaminan mutu pendidikan.

2. Melaksanakan evaluasi pendidikan melalui ujian sekolah oleh sekolah dan ujian nasional yang dilakukan oleh sebuah badan mandiri yaitu Badan
Standar Nasional Pendidikan (BSNP). Ujian nasional mengukur ketercapaian kompetensi siswa/peserta didik berdasarkan standar kompetensi lulusan yang ditetapkan secara nasional.

3. Melaksanakan penjaminan mutu (quality assurance) melalui suatu proses analisis yang sistematis terhadap hasil ujian nasional dan hasil evaluasi lainnya yang dimaksudkan untuk menentukan faktor pengungkit dalam upaya peningkatan mutu, baik antar-satuan pendidikan, antar kabupaten/kota, antar- provinsi, atau melalui pengelompokan lainnya. Analisis dilakukan oleh pemerintah bersama pemerintah provinsi yang secara teknis dibantu oleh Lembaga Penjaminan Mutu Pendidikan (LPMP) pada masing-masing wilayah.

4. Melaksanakan akreditasi satuan dan/atau program pendidikan untuk menentukan status akreditasinya masing-masing. Penilaian dilakukan setiap lima tahun dengan mengacu pada SNP.Hasil akreditasi dijadikan

Sebagai landasan untuk melakukan program pengembangan kapasitas dan peningkatan mutu setiap satuan atau program pendidikan. Pelaksanaan akreditasi ini dilakukan secara independen oleh Badan Akreditasi Nasional Sekolah dan Madrasah (BAN-SM), dan Badan Akreditasi Nasional Pendidikan Nonformal (BAN-PNF).

\section{KESIMPULAN}

Berdasarkan kajian yang dilakukan dibeberapa wilayah Kabupaten Kutai Kartanegara selanjutnya dirumuskan beberapa simpulan sebagai berikut.

Proses pendidikan yang bermutu melibatkan berbagai input, seperti; bahan ajar (kognitif, afektif, atau psikomotorik), metodologi (bervariasi sesuai kemampuan guru), sarana prasarana sekolah, dukungan administrasi dan sumber daya lainnya serta penciptaan suasana yang kondusif.

Peningkatan kualitas pendidikan merupakan suatu proses yang terintegrasi dengan proses peningkatan kualitas SDM melalui berbagai usaha pembangunan pendidikan yang lebih berkualitas antara lain, melalui pengembangan dan perbaikan kurikulum dan system evaluasi, perbaikan sarana pendidikan, pengembangan dan pengadaan materi ajar, serta pelatihan bagi guru dan tenaga kependidikan lainnya.

Guru yang bertugas di Kab. Kutai Kartanegara memiliki rata-rata tingkat pendidikan yang cukup/sedang/menengah dengan jurusan/spesialisasi pada mata pelajaran yang mendukung peningkatan kualitas pendidikan. Untuk mengatasi kekurangan guru, maka pihak sekolah proaktif mengajukan usulan penambahan guru kepada Pemerintah Kabupaten Kutai Kartanegara melalui Dinas Pendidikan. 
Untuk menjaga proses belajar mengajar (PBM) dapat berjalan dengan lancar, maka untuk menutupi kekurangan guru, Kepala Sekolah dapat mendelegasikan kepada guru lainnya yang memiliki kemampuan untuk menyampaikan materi dimaksud.

Masih kurangnya tenaga pendidik (guru) pada bidang studi tertentu mengakibatkan adanya sebagian guru yang harus memegang mata pelajaran yang tidak sesuai dengan keahliannnya/jurusan pendidikan yang dimiliki.

Perlu meningkatkan keikutsertaan para guru dalam seminar, workshop, pelatihan dalam rangka menambah pengetahuan dan memperluas wawasan guru.

Beberapa kendala internal yang dihadapi sekolah di Kab. Kutai Kartanegara, selain masalah sarana sekolah yang kurang dan tenaga kependidikan, yaitu alat peraga/praktek dan akses informasi yang terbatas sehingga lebih banyak menggunakan alat peraga/praktek yang sederhana.

Berbagai temuan dan simpulan dari hasil kajian ini sangat penting sebagai dasar untuk merumuskan kebijakan konkrit bagi upaya peningkatan mutu pendidikan di Kabupaten Kutai Kartanegara. Peningkatan mutu pendidikan patut didukung, karena secara langsung dan tidak langsung erat kaitannya dengan peningkatan kualitas SDM. Oleh sebab itu diperlukan program manajemen peningkatan mutu pendidikan berbasis sekolah yang terpadu, berkesinambungan, dan bersifat kontekstual.

\section{Rekomendasi}

Berikut ini disajikan beberapa rekomendasi yang perlu memperoleh perhatian dalam upaya meningkatkan mutu pendidikan di Kabupaten Kutai Kartanegara.

Peranan pemerintah melalui Dinas Pendidikan Kab. Kutai Kartanegara berserta instansi terkait sangat diharapkan untuk melakukan analisis kebutuhan guru setiap tahun secara kontinyu, disamping perbaikan dan peningkatan sarana sekolah, alat peraga/praktek, dll, sesuai dengan kebutuhan masing-masing sekolah.

Menerapkan strategi pembangunan pendidikan yang tidak berdasarkan pada input oriented saja, tetapi juga harus lebih memperhatikan faktor proses pendidikan.

Pemerintah Daerah melalui Dinas Pendidikan hendaknya memberikan kepercayaan kepada sekolah untuk mengatur dan mengurus dirinya sendiri sesuai dengan kondisi lingkungan dan kebutuhan anak didiknya, sehingga sekolah bisa lebih dinamis dan kreatif dalam melaksanakan perannya sebagai pelaksana pendidikan formal guna peningkatan mutu pendidikan.

Program peningkatan intelektual/kompetensi guru hendaknya dapat terus diprioritaskan, melalui sarana/media yang bisa membantu guru untuk mengakses teknologi informasi lebih luas tentang wacana pendidikan terkini.
Pemanfaatan dana Bantuan Operasional Sekolah (BOS) harus sesuai dengan fungsi dan tujuan program BOS, serta penyaluran dana secara transparan dan akuntabel.

Evaluasi Pendidikan hendaknya dilakukan oleh pemerintah secara kontinyu terhadap perkembangan pendidikan di Kabupaten Kutai Kartanegara, sehingga diproyeksikan sekolah dan anak didik mampu bersaing di era globalisasi.

\section{Daftar Pustaka}

Arikunto, Suharsim. 2000. Dasar-dasar Evaluasi Pendidikan. Penerbit: Bumi Aksara Jakarta

Hadis, Abdul, dan Nurhayati. 2010. Manajemen Mutu Pendidikan. Penerbit: Alfabeta Bandung

Irawan, Suhartono. 2000. Metode Penelitian Sosial. Penerbit: PT. Rosda Karya Bandung

Singarimbun, Masri, 2008, Metode Penelitian Sosial. Penerbit: LP3ES Jakarta

Sondang, P Siagian. 2009. Kiat meningkatkan Produktifitas Kerja. Penerbit: Rineka Cipta Jakarta.

Sulistiani, Ambar Teguh, dan Rosidah. 2003. Manajemen Sumberdaya Manusia. Penerbit: Graha Ilmu Yogyakarta.

Sondang, P. Siagian. 1998. Manajemen Abad Ke- 21. Penerbit: Bumi Aksara Jakarta

Soedijarto, H. 2003. Pendidikan Nasional sebagai Proses Transformasi Budaya. Penerbit: Balai Pustaka, Jakarta.

Tirtaraharja, Umar dan Sula. SL .2005. Pengantar Pendidikan. Penerbit: Rineka Cipta Jakarta.

Umaedi. 1999. Manajemen Peningkatan Mutu Berbasis Sekolah. Penerbit: Bumi Aksara Jakarta.

Undang- undang No. 20 Tahun 2003 tentang Sistem Pendidikan Nasional

Undang-Undang No. 32 Tahun 2004 tentang Pemerintah Daera

Undang- undang No. 14 Tahun 2005 tentang Guru dan Dosen

Peraturan Pemerintah No. 19 Tahun 2005 tentang Standar Nasional Pendidikan 
